Anatolian Journal of Education

e-ISSN: 2547-9652@www.e-aje.net

\title{
The Content Of Indonesian Language Syntactic Learning Instrument Based On The Need Analysis Directed To The Indonesian Language And Literature Education Department Students Among The Universities In Surakarta Indonesia
}

Tutik Wahyuni, Email: tutik21161@gmail.com

Surakarta and lecturer in University of Veteran Bangun Nusantara Sukoharjo

Sarwiji Suwandi. Email: sarwijiswan@yahoo.com

University of Sebelas Maret Surakarta

St. Y, Slamet. Email: slametsty@yahoo.co.id

University of Sebelas Maret Surakarta

Andayani. Email: bu_anda09@yahoo.co.id

University of Sebelas Maret Surakarta

\begin{abstract}
This article studied the content of Indonesian Language Syntactic learning instrument based on the need analysis directed to the Indonesian Language and Literature Education Department (Pendidikan Bahasa dan Sastra Indonesia $=\underline{\text { PBSI) }}$ students coming fromthe various universities in Surakarta, Indonesia. It aims to: (1) describe and explain the content of Syntactic learning instrument used for the students (2) describe and explain the appropriate model of Syntactic learning instrument used by lecturers and students. It reveals that some Syntactic learning instruments distributed in the form of textbooks recently only contain theoretical reviews which only acquaints the cognitive needs but push aside both psycho motoric and affective needs. Based on the need analysis of lecturers and students, the learning instruments regarded show the gap of communication of the Linguistic function and are not in compliance to the curriculum. Therefore, the revision of learning instruments based on the need analysis, curriculum development and the students' characteristics must be endeavored. The study was completed through observation, interview, document analysis and survey conducted to analyze the quality of the learning instruments used. Besides, it will give a foundational benefit to elevate the prototype of a new learning instrument. The survey shows that there has not been the appropriate learning instrument synchronous, either with to the curriculum designed or the students' characteristics. The process conducted finally resulted the draft of learning instrument which is in compliance to the needs of lecturers and students. It will be developed using contextual approach, including: constructivism, inquiry, peer learning, demonstration, reflection and authentic assessment.
\end{abstract}

Keywords: Content of Syntactic Learning Instrument, Need of Learning Instrument, PBSI Lecturers and Students. 


\section{Introduction}

This study focused on the content of Syntactic learning instrument based on the need analysis done to PBSI students coming from the universities distributed in Surakarta, Indonesia. The reason why Indonesian Language Syntactic material is hard to be accomplished by the students is the lack of comprehension. The limited reference used as the review becomes the problem as well. For instance, Syntactic learning instruments normally distributed nowadays are arranged as textbooks which are complicated to explore. Besides, they present the materials in incomplete aspects (different with the curriculum concept). Simply, the learning instruments provided are not based on the lecturers and students' needs. Some lecturers are even stuck to use textbooks provided by the department without considering whether it can be effectively applied in lecture.Some Syntactic textbooks published nowadays normally have not matched to the standard criteria of an ideal learning instrument. The incomplete discussion provided there are hard to comprehend and only create a monotonous lecture. The incomplete state meant is the disharmony between the theories exposed and reality.

\section{Review of Literature}

This problem is generally found in some textbooks presented using structural approach (Ramlan, 2001: 6; Chaer, 2009: 10; Markhamah (2010: 2), Sukini (2010: 2), Arifin dan Junaiyah (2009: 1), Parera (2009: 3). The study explored that the textbooks used by PBSI students in the universities of Surakarta only contain lots of theoretical reviews and cover the cognitive need, while both psycho motoric and affective need are away from the discussion. Besides, the discussions are only presented using simple sentences.

Sidu's Sintaksis (2012) has used contextual approach in its explanation as one of the criteria of a good learning instrument. . It has been developed based on the need analysis with 7 elements including constructivism as the principle that learning is a knowledge 'constructing' instead of transferring process, inquiry from observing to comprehending, questioning as the effort to encourage, guide and evaluate the students' thinking process, learning community as the concept of establishing a corporative peer learning process to afford better result, modelling as the display of materials conveyed, reflection as the comprehension established after the learning process, authentic assessment as the effort to give a relevant measurement for the learning outcome using contextual approach. In compliance to the concept, Zhan stated, "Communicative competence plays an important role in language teaching and learning. In this paper, the author makes a tentative effort to explore the children's acquisition of communicative competence in order to help FL learners have a better understanding of the formation of this ability" (Zhan, 2010; Utami, 2013). In other words, the communicative competences is significant inside the process of language teaching and learning. This article also discusses the children's communicative competences in the study of language acquisition, in order to shape their knowledge toward the competences they have to master.

Similar to the previous study, Zhang (2010: 81-81) explained, "The paper tries to show the positive effects of cooperative language learning on foreign langue learning and teaching. Compared with traditional language teaching, cooperative language learning conforms to the developmental trend of language teaching method and possesses considerable advantages. In the foreign language learning classrooms, 
cooperative language learning provides students with the necessary academic and social skills. The paper reveals cooperative learning benefits language learning in many aspects". Therefore, this article tries to explain both positive and negative impacts in the cooperative process of language teaching and learning. Compared to the conventional language teaching, cooperative language teaching give more benefits to train the students in having a good comprehension of social intelligence and skill.

In compliance to Zhan's explanation, Changjuan contributed the idea in Acquisition of Communicative Competence from Journal of Language Teaching and Research, stating that communicative competence is the linguistic interaction in target language including the ability to function in the communicative setting of spontaneous transaction done by more than one individual.

In Topics in Linguistics - Issue 3 - July 2009 - Interface Between Pragmatics and Other Linguistic Disciplines from International Journal of Linguistic (issue 3),

Povolná (2009: 54) discussed "Negotiation of Meaning in Spoken Interaction" and explained that the signs given in the communication process is functioned to

elucidate the aim of communication of meaning negotiation and oral interaction thus can show the discourse coherence.

A learning instrument is different with a textbook. Generally the target of learning process formulated by the author of a particular textbook is not similar to the curricular aim of an educative program (Tomlinson and Mashuhara, 2004: 162). The use of kinds of commercial learning instrument as the material source conveyed at school is a prevalent condition. The lecturers can use it as the handbook and guidance to elevate the learning process, respond the students' early skill and inputted materials and interpret the tasks and exercises.

The essence of learning instrument means as the key element of a particular language program, including the materials prepared particularly for the institution or the one for the lecturers and teachers (Richards, 2001: 257; Cunningsworth, 1995: 24). The novice lecturer even can use the learning instrument to establish lesson plans or as the guidance to hold the teaching process. Richards (2001: 273) explained that a good learning instrument should have some qualifications to: (1) encourage the students to learn; (2) construct a ground of thought which directs them to construct previous materials learnt; (3) inform the next materials in detail; (4) elucidate what new materials to learn; (5) connect the ideas to what they have understood; (6) motivate them to have a sense toward the new materials; (7) help them to get the feedback; (8) help them to retell what they have gained in the learning process; (9) ensure them that they know what to do; (10) give them an opportunity to check their achievement; and (11) help them to learn better than before.

\section{Method}

The data analysis of this article is conducted through qualitative and quantitative methods. The data analysis process is explained as follows: it applies interactive qualitative analysis consisting of three components: (1) data reduction; (2) data display; and (3) verification (Miles and Huberman, 1992: 20). The method used is qualitative descriptive consisting of 3 stages of process as follows:

\section{Document Analysis}

It contains review done toward the curriculum, syllabi and lecture quality planning, Syntactic journal and the learning instruments provided. The survey was conducted for 6 months in 4 universities distributed in Surakarta, consisting of 3 private universities including University of Veteran Bangun Nusantara Sukoharjo (Universitas Veteran Bangun Nusantara Sukoharjo - UNIVET BANTARA 
Sukoharjo), University of Muhammadiyah University Surakarta (Universitas Muhammadiyah Surakarta - UMS) and University of Widya Dharma University Klaten (Universitas Widya Dharma Klaten - UNIWIDHA) and 1 state university including University of Sebelas Maret Surakarta (Universitas Sebelas Maret Surakarta - UNS). The survey brought up a conclusion that these universities have not provided sufficient learning instruments for Indonesian Language Syntactic materials used to conduct the lecture.

\section{Interview}

The respondents of the interview were the lecturers, students and other readers of the learning instruments in order to explore the quality of the learning instruments.

\section{Observation}

The data sources used to support the observation includes: (1) respondents who were the lecturers of Indonesian Language Syntactic lecture in the universities in Surakarta, including UNIVET BANTARA Sukoharjo, UMS, UNWIDHA and UNS; (2) textbooks used as the learning instruments or references in the Syntactic lecture.

These steps were accomplished by noting all the sentences contained in the learning instrumentsprovided in 3 private universities and 1 state universities in Surakarta regarded in order to extract the data for the research. The next step was to refer the theories and concepts in compliance to this research.

\section{Findings}

\section{The Content of Indonesian Language Syntactic Learning Instrument Based on The Need Analysis of Students and Lecturers}

\section{The Condition of Indonesian Language Syntactic Learning Instrument in The Universities in Surakarta}

The exploration was conducted to collect the information and solution to solve the recent status of the problem through field observation and in-depth interview. The condition of Indonesian Language Syntactic learning instruments were observed based on the field note of document analysis (Catatan Lapangan Hasil Analisis Dokumen CLHAD) and filed note of interview (Catatan Lapangan Hasil Wawancara CLHW). The information gained was used as the foundation to design the draft of an ideal Syntactic learning instrument. This article explored 5 Indonesian Language Syntactictextbooks used as the learning instruments in the universities regarded. They included Ramlan's Sintaksis (Syntactic), Sidu'sSintaksis Bahasa Indonesia (Indonesian Language Syntactic), Sukini'sSintaksis Sebuah Panduan Praktis (Syntactic As A Practical Guide), Markhamah'sRagam dan Analisis Kalimat Bahasa Indonesia (Mode and Analysis of Sentences in Indonesian Language) and Parera's Dasar-Dasar Analisis Sintaksis (Basic Syntactic Analysis).

\section{Indonesian Language Syntactic Learning Instrument for PBSI Students in The Universities in Surakarta}

Based on the survey conducted for 6 months in 4 universities including UNIVET BANTARA Sukoharjo, UMS, UNWIDHA and UNS, there were not found many learning instruments of Indonesian Language Syntacticmaterials. They need more learning instruments to make the lecture process of Indonesian Language Syntactic materials better. 
Indonesian Language Syntactic TextBooks Used by PBSI Students in University of
Veteran Bangun Nusantara Sukoharjo (UNIVET BANTARA Sukoharjo)

UNIVET BANTARA Sukoharjo has not provided Indonesian Language Syntactic learning instruments. It only uses a general textbook of Ramlan'sSintaksis and completed by La Ode Sidu'sSintaksis Bahasa Indonesia (2012).

The scope of materials conveyed in those textbooks including: (1) Linguistic strata; (2) Syntactic strata; (3) Syntactic function; (4) Semantic role of sentences; (5) effective sentence; and (6) conjunction. Sidu's Sintaksis Bahasa Indonesia contains some advantages and lacks. The table of contents given in the front page makes the user easy to find some specific chapters, sub-chapters and topics contained. However, it does not provide a summary to help the readershave a sense of what the textbook represents, since it becomes a brief description of key concepts in every chapter wrapped in short, brief and easy understood content to help them get the whole content.

Sidu's Sintaksis Bahasa Indonesia is different to Ramlan's Sintaksis, that it begins with a broader scope about Linguistic definition including Phonology, Morphology and Syntactic. What makes them similar is the scope of grammatical strata using structural approach. The materials contained directs to the cognitive field with a theoretical and scientific characteristic. However, both psycho motoric and affective field have not been considered well.

The conveying of materials is too limited using short information. After the concept is explained, some relevant examples placed in the middle of the explanation using simple sentences.

The language used in Sidu's Sintaksis has fulfilled the ideal criteria of learning instrument of being easy understood by the students, teachers, lecturers and linguists. The whole criteria regarded concludes that the textbook as the learning instrument must be communicative and easy to understand.

\section{Indonesian Language Syntactic TextBooks Used by PBSI Students in University of Muhammadiyah Surakarta (UMS)}

UMS has not provided Indonesian language Syntactic learning instruments. It only uses Ramlan's Sintaksis textbook as the primary guide, while the secondary ones coming from the lecturers, such as Markhamah's Sintaksis, Ragam dan Analisis Kalimat dalam Bahasaa Indonesia published in 2008 and Sintaksis 2: Keselarasan Fungsi, Kategori, Peran dalam Klausa published in 2010.

Both contain lots of teoretical reviews covering the cognitive field (knowledge), but do not touch either psycho motoric or affective field. Therefore, the textbooks has not matched to the aim of an ideal teaching. They do not include either summary or evaluation. Summary is the key concept of every chapter presented in succinct, brief and easy to understand arrangement.

\section{Indonesian Language Syntactic Learning Instrument for PBSI Students in University of Widya Dharma Klaten (UNWHIDHA)}

UNWIDHA becomes the one and only university of all involving in this research having textbook entitled Sintaksis: Sebuah Panduan Praktis (Syntactic: A Practical Guide) authored by the lecture named Sukini in 2010.The textbook regarded still irrelevant to the ideal learning instrument. The ideal learning instrument should contain standard of competence, basic competence, indicator, learning materials, learning activities and tests. All of those components must be attached in every chapter of a textbook. Sukini's Sintaksis: Sebuah Panduan Praktis has not been totally 
complete to fulfill the requirements, since it only contains basic competence summarized at page xvi of Analisis Instruksional (Instructional Analysis).

Bloom (in Tarigan, 2009: 137) explained 3 area of teaching including cognitive, affective and psych motoric field. Cognitive field refers to the theoretical knowledge. Affective field refers to the behavior which affects the personality. While psycho motoric field refers to the skill. It is concluded that affective and psycho motoric fields are not touched in this textbook.

\section{Indonesian Language Syntactic Textbook for PBSI Students in University of Sebelas Maret Surakarta (UNS)}

UNS has not provided Indonesian Language Syntactic learning instruments. It only uses Ramlan's Sintaksis textbook as the primary source and the other books authored by the expert outside UNS s the secondary one. The secondary sources is Parera's Dasar-dasar Analisis Sintaksis published in 2009.

According to the strata of grammatical unit in Syntactic study, phrase is the smallest unit. While, the textbook does not contain summary, exercises and reflection to the materials thus cause the students cannot get the confirmation to what materials they should emphasize on. It is not completed with the evaluation such as tasks, practices or questions directed to the students. The measurement toward the students' achievement does not flow through the procedural process.

It tends to use complicated theories, formula and symbols to explain the elements of sentences. Moreover, it often inserts the comparison of English. It uses the formula of foreign language and give less concrete instances. There used less concrete instances taken from Indonesian Language. It uses the instances coming from English translation, thus they are not matched to the contextual needs.

\section{The Need of Learning Instrument}

Need analysis becomes the main factor grounding the arrangement of a good learning instrument. Therefore, the content must be in compliance with the need of lecturers and students. The study of the lecturers' need analysis at the exploration step was conducted through the interview toward 4 lecturers from 4 different locations in different time as well (representatives of UNIVET BANTARA Sukoharjo, UNWIDHA, UMS and UNS). The informants were selected based on their skill and competence in Syntactic materials. Besides, the selection was considered from their ability to convey their notion about the compliance of the learning instrument they had used this time.

Need analysis is started by holding a theoretical review and field study. This processes are conducted to identify the need of learning instrument, including: (1) for the lecturers; (2) for the students; and (3) description of the result.

\section{The Need Of Learning Instrument Based On The Lecturwes' Point Of View}

The need of learning instrument based on the lecturer's point of view was explored using document analysis and interview. Using the instrument of field and filed note of interview (Catatan Lapangan Hasil Wawancara), the lecturer was known to have a problem of being difficult to comprehend the Indonesian Language Syntactic textbooks. The need identification was conducted then to get a kind of information about learning instrument which they (lecturer $\mathrm{A}$ and $\mathrm{H}$ ) want to use, such as: 
First, the one used in the University of Widya Dharma Klaten, as considered good, even if it contained some lacks. The arrangement of learning instrument include some elements such as standard of competence, basic competence, indicator, learning outcome, learning materials, learning procedure, evaluation and reflection. Besides, tasks and exercises should be attached to improve students' activities. However, University of Widya Dharma Klaten (UNWIDHA) does not have those elements completely in the learning instrument used.

Second, a good learning instrument should have given the variation of examples in order to improve the students' comprehension. It should consider the context of phrase, clause, sentence and discourse. Besides, it should have given the variation of sentence patterns using subject-predicate-object, subject-predicate-complement, subject-predicate-object-adverb and others. Thus can be seen that those patterns come from standardized variations. Those patterns can be found from the knowledge variation, either in oral or written communication. However, the knowledge variation is not the only one absolutely used in all kinds of context. There needs to explore other variation used. For instance, Indonesian language speakers use a kind of nonstandardized variation in communication. The authors of Syntactic textbook need to expose those variations by examples. Since every speaker ever practiced the different structure of the sentences they uttered or written based on the situation or context they are involving in.

Third, the examples given in the textbook as the learning instrument should have represented the Indonesian Language variation to afford the total comprehension of the readers. If a particular textbook only shows one particular variation, it will create the understanding of the readers that the variation exposed is the only one permitted in the social dimension in all the situation. The use of other kinds of variation will motivate the readers to conclude the language characteristics and bring out the notion that Indonesian Language has more than one variations.

Fourth, the learning instrument must be based on the context. The examples should have been completed by the context. It could be in a dialogue or discourse. It would help the readers to identify the speakers involved in the context, media, aims and other things.

Fifth, the quality of a sentence does not always refer to the complete elements of function but the meaning conveyed. Therefore, the author of Syntactic textbooks should present the alternative answers.

Sixth, There were found some irrelevant materials in Ramlan's Sintaksis, for instance the interrogative sentences at page 12 and 13 (CLHAD). There are many data which actually do not need to be attached in nowadays Syntactic textbooks. For instances, the element of Si Boy in the construction of Ongky 'Si Boy' Alexander, Jamu in the construction of Marta 'Jamu' Tilaar, Semar in the construction of Gus 'Semar' Dur,

Si Tenda Biru in the construction of Desi 'Si Tenda Biru' Ratnasari and Jacko in the construction of Michael 'Jacko' Jackson. Si Boy and Si Tenda Biru belongs to the nomina phrase. However, after they are put into the word area, will the construction of Ongky 'Si Boy' Alexander and Desi 'Si Tenda Biru' Ratnasari remain as phrase or change as word? The similar data need to be discussed in the Syntactic textbooks. Both segmental and supra-segmental elements must be explained in the sentence characteristics. The author of Syntactic textbooks generally only explain the area of phrase, word, clause and sentence. There are words which actually are words indeed, and words which actually are sentences. As well as phrases which actually are phrases indeed, and phrases which actually are sentences. The supra-segmental element can distinguish the differences of the Syntactic field. 


\section{The Need of Learning Instrument on The Student E' Point of View}

Based on the interview conducted with the students as the informants (student $\mathrm{N}, \mathrm{E}$ and $\mathrm{P}$ ), they stated that learning instrument is an important learning source, thus they need it. They stated that the learning instrument should: (1) contain complete, brief, compact and easy to understand materials; (2) expose materials contextually taken from daily life.

The result of interview conducted with the lecturers and students concluded that Syntactic learning instrument needed to be developed using contextual approach. There are 7 criteria of qualified learning materials follows: using of media such as figure, diagram and mapping, grouping the learning community, motivating the students to be actively involved in the teaching and learning process (constructivism), commanding the students to distinguish the simple and compound sentences (inquiry), encouraging the students to ask, reflecting and make the lecturers to establish a good relation to the students. The interview concluded that the lecturers had conducted a good contextual approach in conveying the Syntactic materials.

\section{The Description Of Studied Learning Instruments}

Learning instrument is one of the dominant facilities used to support the learning process and as the guide to conduct the lecture. That is the reason why the lecturers need the learning instruments a lot. This point is supported by the identification of the informants' (students) needs stating that learning instrument is used to elevate their comprehension.

As the consideration to arrange a prototype of learning instrument contextually, there needs to be completed by tasks, exercises and approaches. However it is restrained by the lack of support of finance and professionalism of the lecturers.

The solutions toward the problem of arranging the learning instrument can be described as follows: (1) it should be arranged relevantly; (2) it should emphasize on the communicative exercises for the students; (3) it should apply an interesting approach to encourage the students to involve in communication using appropriate sentences; (4) it should present easy to understand materials; (5) it should be able to establish an optimum independent learning; (6) it should accommodate the students' needs toward the Indonesian Language Syntactic materials in Higher Education. Based on the identification of need analysis of the learning instrument and the learning instruments provided, the development conducted contextually should include the criteria below:

First, it should be arranged according to the curricula.Second, it should elevate the competence of communication according to the essence of language function in communication based on the curricula. The communication skill should not be dominated the knowledge variation only.

Third, the learning instrument arranged using contextual approach should be implemented in authentic exercises and tasks, eitherby individual or group. Fourth, syllabi and lesson plan should be developed through an analysis of communicative skills in Higher Education by grouping the basic competence related to the topic discussed and conducted in a continuous learning. The revision of lecture agenda should be situational in giving the materials, tasks and exercises.

Fifth, text selection in the learning instrument must be in compliance to the needs. The use of heterogeneous context helps to find some specific data such as the variation of 
incomplete clause garishly used in newspapers nowadays. If the Syntactic textbooks keep sticking on the pattern of subject-predicate, those variations will not be touched and remain as an unresolved phenomenon of language in daily interaction.

Sixth, the use of learning instrument should be developed according to the students' needs. Seventh, the use of learning instrument should be developed alongside with the information sharing of sufficient learning materials. Eighth, the learning instrument should be a worthy learning source for lecturers and students. Ninth, learning instrument should touch and elicit intelligence and affective area.

Tenth, syllabi and lesson plan should contain scoring. Eleventh, the learning instrument should consist of: (a) standard of competence; (b) basic competence; (c) indicator; (d) mapping; (e) learning materials; (f) summary; (g) tasks; (h) exercises; (i) reflection; and (j) tests.

\section{Conclusion}

The Indonesian Language Syntactic learning instrument for PBSI students in the universities in Surakarta are still irrelevant to the lecturers and students' needs, since they only apply structural approach which covers the cognitive needs and do not touch both psycho motoric and affective needs. They are needed to be revised to find the relevance using contextual approach including constructivism, inquiry, questioning, learning community, modelling, reflection and authentic assessment by taking the daily life examples as the function of language to communicate.

\section{References}

Akrekar R, Joshi M. 2008. .Natural Language Interface Using Shallow

Parsing.International Journal of mputer Science and Applications; 5(3):70-90.

Arifin, E. Zaenal 2009. Sintaksis.Jakarta: Gramedia.Devi, V Bavani 2013. International Research Journal of Pharmaceutical and Applied Sciences (IRJPAS)

Available online at www.irjpas.comInt. Res J Pharm. App Sci., 2013; 3(5):249252Available online at www.irjpas.com

Eisenbeiss, Sonja. 2009."Generative approaches to language learning." Linguistics: an interdisciplinary journal of the language sciences 47.2 (2009): 273+. Gale Education, Religion and Humanities Lite Package. Web. 5

Horrocks, G., \& Stavrou, M. (1987). Bounding theory and Greek syntax: Evidence for whmovement in NP, Journal of Linguistics, 23,79-108.

M. Lewis.2013. Linguistics: an interdisciplinary journal of the language sciences. 49.2 (March. 2011): p415. From Gale Education, Religion and Humanities Lite Package.

Keraf, Gorys. 1991. TataBahasa Indonesia.Ende : Nusa Indah Ende Flores.

Parera, J.D. 2009. Dasar-dasar Analisis Sin-taksis. Jakarta : Erlangga. 
Phyue, See Lai, Aye Thida. 2013. 'Unknown Word Detection via Syntax Analyzer'. LAES International Journal of Articial Intelligence (UIJ-AI) vol.2 No.3, September 2013.pp 107-116. ISSN 2252-8938.

Povolna, Renata. 2009.' Negotiation of Meaning in Spoken Interaction ', International Journal Linguistic Purwo, Bambang K.1985.Untaian Teori Sin-taksis 1970-1980-an. Jakarta: Arcan

Ramlan, M. 2001. Ilmu Bahasa Indonesia: Sin-taksis. Yogyakarta: UB Karyono.

Richards, J.C. \& Rodgers, Theodore S. 2001. Approaches and Methods in Language Teaching (New Edition). Cambridge: University Press.

Sidu, La Ode. 2012. Sintaksis Bahasa Indonesia. Kendari: Unhalu Press.

Suhardi.2008.Sintaksis.Yogyakarta: UNY Press.

Sukini, 2010. SintaksisL: Sebuah Panduan Praktis. Surakarta: Yuma

Sultan, Fazal Mohamed Mohamed. 2009.Syntactic Structure Of Bateq's Noun Phrase GEMA Online Journal of Language Studies 47Volume 9(1).

Tarigan, Henry Guntur.1985. Prinsip-prinsip Dasar Sintaksis . Bandung: Angkasa.

Tomlinson, Brian \& Mashuhara, Hitomi. 2004. Developing Language Course Materi als. Singapore: SEAMEO

Rwakakindo, Ibrahin Domician. 2015.' The Syntactico-Semantic Proficiency of Written English Langage for Undergraduate Students in Tanzania ". Journal of Literature, Languages and Linguistic. ISSN 2422-8435. An International Peerreviewed Journal vol 16.

Verhaar, J.W.M. 2006. Asas-asas Linguistik Umum. Yogyakarta : Gadjah Mada University Press.

Verhagen, Arie. 2008. Constructions of Intersubjectivity: Discourse, Syntax, and Cognition Author(s): Barbara Dancygier Source: Linguistics: an interdisciplinary journal of the language sciences. 46.3 (May-June 2008): p658. From Gale Education, Religion and Humanities Lite Package.

Victor, Kebande Rigworo, Karani Nyachiro Nelson. 2013. 'Formal Semantics, Syntax, Pragmatics: An Essence of Programming Language Desibn'.Academic International. ISSN 2223-9553, ISSN 2223-9944. Vol. 4 No.2 March 2013.

Zhan, Changjuan. 2010. "Acquisition of Communicative Competence'.Journal of Language Teaching and Research ISSN 1798-4769Volume 1, Number 1, January.

Zhang, Yan. 2010. “'Cooperative Language Learning and Foreign Language Learning and Teaching', Journal of Language Teaching and Research SSN 1798-4769

Volume 1, Number 1, January. 